ISSN: $2339-2479$

DOI: $10.14692 /$ jfi.10.1.17

\title{
Sensitivitas Metode Serologi dan Polymerase Chain Reaction untuk Mendeteksi Bean Common Mosaic Potyvirus pada Kacang Panjang
}

\section{Sensitifity of Serology and Polymerase Chain Reaction Methods for Detection of Bean Common Mosaic Potyvirus in Yard Long Bean}

\author{
Sherli Anggraini, Sri Hendrastuti Hidayat* \\ Institut Pertanian Bogor, Bogor 16680
}

\begin{abstract}
ABSTRAK
Penyakit mosaik kacang panjang yang disebabkan Bean common mosaic potyvirus (BCMV) merupakan penyakit penting yang berpengaruh pada produksi tanaman. Metode umum untuk mendeteksinya ialah dengan serologi dan polymerase chain reaction (PCR). Penelitian ini bertujuan mengevaluasi tiga metode deteksi, yaitu indirect enzym-linked immunosorbent assay (I-ELISA), dot immunobinding assay (DIBA), dan reverse transcription (RT)-PCR yang sensitif sebagai metode diagnosis BCMV pada kacang panjang. Sampel yang digunakan adalah isolat BCMV asal Cirebon yang dipelihara pada tanaman kacang panjang di rumah kaca. Batas sensitivitas masing-masing metode diuji melalui pengenceran cairan perasan tanaman dan antiserum untuk I-ELISA dan DIBA serta cDNA sebagai template pada RT-PCR. Batas sensitivitas masing-masing metode berbeda-beda, metode I-ELISA ialah pada tingkat pengenceran cairan perasan $10^{-3}$ dan pengenceran antiserum $10^{-2}$, metode DIBA ialah pada tingkat pengenceran cairan perasan $10^{-5}$, dan metode RT-PCR pada pengenceran cDNA $10^{-4}$.
\end{abstract}

Kata kunci: enzym-linked immunosorbent assay, dot immunobinding assay, reverse transcription-polymerase chain reaction

\begin{abstract}
Mosaic disease in yard long bean is caused by Bean common mosaic potyvirus (BCMV) and has been reported to affect yield. Common method to detect infection of BCMV involves serological assay and polymerase chain reaction (PCR). The aims of this research is to assess the sensitivity of three methods, i.e. Indirect Enzym-Linked Immunosorbent Assay (I-ELISA), Dot Immunobinding Assay (DIBA), and reverse transcription (RT)-PCR as detection method for BCMV infection in yard long bean. Sensitivity level of the methods was evaluated by diluting plant extract and antisera for I-ELISA and DIBA, and cDNA as template in RT-PCR. Virus isolate from Cirebon was maintained in yard long bean in screenhouse and used for the assessment. Absorbance value of ELISA showed that dilution end point for I-ELISA was reached at $10^{-3}$ and $10^{-2}$ of plant extract and antisera dilution, respectively. Positive infection was still detected using DIBA when the plant extract was diluted up to $10^{-5}$ based on development of color intensity on nitrocellulose membrane. Specific viral DNA fragment was still amplified when cDNA was diluted up to $10^{-4}$, indicated higher sensitivity level of RT-PCR method.
\end{abstract}

Key words: enzym-linked immunosorbent assay, dot immunobinding assay, reverse transcription-polymerase chain reaction

*Alamat penulis korespondensi: Departemen Proteksi Tanaman, Fakultas Pertanian, Institut Pertanian Bogor, Jalan Kamper, Kampus Darmaga, Bogor 16680

Tel: 0251-8629364, Faks: 0251-8629362, Surel: srihendrastutihidayat@gmail.com 


\section{PENDAHULUAN}

Bean common mosaic potyvirus (BCMV) termasuk dalam famili Potyviridae, kelompok virus tumbuhan yang terbesar. Virus ini terbawa benih yang dapat ditularkan secara mekanis melalui cairan perasan tanaman dan ditularkan secara nonpersisten oleh beberapa jenis kutudaun termasuk Aphis craccivora (Nalini et al. 2006). Penyakit mosaik yang disebabkan oleh BCMV merupakan penyakit penting pada tanaman kacang-kacangan karena dapat menyebabkan kehilangan hasil hingga 98\% (Verma dan Gupta 2010). Sejak tahun 2008 persentase insidensi penyakit mosaik kacang panjang dilaporkan di beberapa daerah di Jawa Barat, Jawa Tengah, dan Banten meningkat. Damayanti et al. (2009) melaporkan bahwa salah satu virus yang berasosiasi dengan penyakit mosaik tersebut ialah Bean common mosaic potyvirus.

Metode yang umum dilakukan untuk mendeteksi infeksi virus pada tanaman adalah uji serologi yang didasarkan pada reaksi antara antigen (virus) dan antibodi, seperti metode enzyme-linked immunosorbent assay (ELISA) (Nalini et al. 2006; Verma dan Gupta 2010), metode gel double-diffusion test, dot immunobinding assay (DIBA), immunoblotting atau western blotting (Xie et al. 2013). Metode deteksi lain yang sering digunakan dewasa ini ialah metode deteksi molekuler polymerase chain reaction (PCR) yang memanfatkan sifat spesifik urutan nukleotida virus. Pemilihan metode deteksi yang tepat sangat menentukan hasil deteksi karena metode yang kurang baik akan menyebabkan kesalahan pada identifikasi penyebab penyakit.

Penelitian bertujuan mengevaluasi tiga metode deteksi virus, yaitu ELISA, DIBA dan RT-PCR sebagai metode yang sensitif untuk mendeteksi infeksi BCMV pada kacang panjang.

\section{BAHAN DAN METODE}

\section{Sumber Inokulum Virus}

Isolat BCMV yang digunakan berasal dari Cirebon yang merupakan koleksi Laboratorium
Virologi Tumbuhan, Departemen Proteksi Tanaman, Fakultas Pertanian, Institut Pertanian Bogor. Isolat tersebut diperbanyak pada tanaman kacang panjang varietas Parade melalui penularan secara mekanis.

\section{Metode Indirect Enzyme-Linked \\ Immunosorbent Assay}

Sampel daun tanaman terinfeksi BCMV digerus dalam buffer coating dengan perbandingan 1:100 (b:v). Cairan perasan tanaman hasil gerusan sebanyak $100 \mu \mathrm{L}$ dimasukkan ke dalam masing-masing sumur pada plat mikrotiter ELISA dan diinkubasi pada suhu $4{ }^{\circ} \mathrm{C}$ selama 24 jam. Sap tanaman dibuang dan sumur dicuci dengan phosphate buffer saline tween-20 (PBST) sebanyak 7 kali. Anti serum BCMV dilarutkan dalam bufer ECL (2 g bovine serum albumin, 20 g PVP, $0.2 \mathrm{~g} \mathrm{NaN}_{3}$ ) dengan perbandingan 1:200 (b:v), selanjutnya sebanyak $100 \mu \mathrm{L}$ antiserum BCMV dimasukkan ke dalam sumur plat mikrotiter ELISA dan diinkubasi pada suhu $37{ }^{\circ} \mathrm{C}$ selama 2 jam. Sumur dicuci kembali dan kemudian diisi dengan $100 \mu \mathrm{L}$ konjugat yang dilarutkan dalam bufer ECL dengan perbandingan 1:1000 (b:v) dan diinkubasi pada suhu ruang selama 2 jam. Sumuran dicuci kembali sebanyak 7 kali dengan PBST, selanjutnya diisi dengan $100 \mu \mathrm{L}$ PNP yang dilarutkan dalam bufer PNP. Setelah diinkubasi pada suhu ruang selama 30 menit pengamatan dilakukan secara kuantitatif menggunakan ELISA reader (Bio-RAD 550) pada panjang gelombang $405 \mathrm{~nm}$. Reaksi dihentikan dengan cara menambahkan larutan $\mathrm{NaOH} 3 \mathrm{M}$ dalam masing-masing sumur. Pada setiap pengujian disertakan kontrol negatif, yaitu tanaman sehat dan bufer.

Evaluasi metode I-ELISA dilakukan untuk menentukan batas sensitivitas, yaitu dengan mengencerkan sap tanaman dan antiserum. Sap tanaman diencerkan secara berseri sampai $10^{-6}$ dan antiserum diencerkan hingga $10^{-5}$.

\section{Metode Dot Immunobinding Assay}

Metode DIBA dilakukan berdasarkan metode Mahmood et al. (1997). Membran nitroselulosa direndam dalam metanol $100 \%$ 
selama 10 detik dan dikeringanginkan. Jaringan daun tanaman terinfeksi BCMV digerus dalam tris buffer saline (TBS:Tris$\mathrm{HCl} 0.02 \mathrm{M}$ dan $\mathrm{NaCl} 0.15 \mathrm{M}, \mathrm{pH}$ 7.5) dengan perbandingan 1:10 (b/v). Sebanyak $10 \mu \mathrm{L}$ cairan perasan tanaman diteteskan di atas membran nitroselulosa. Setelah tetesan sampel kering, membran direndam di dalam $10 \mathrm{~mL}$ larutan blocking non-fat milk 2\% dalam TBS yang mengandung Triton X-100 dengan konsentrasi akhir 2\%. Membran kemudian diinkubasi pada suhu ruang sambil digoyang dengan kecepatan $50 \mathrm{rpm}$ selama 2 jam dengan menggunakan EYELA multi shaker MMS. Membran kemudian dicuci 5 kali dengan $\mathrm{dH}_{2} \mathrm{O}$, setiap pencucian berlangsung 5 menit sambil digoyang dengan kecepatan $100 \mathrm{rpm}$. Membran selanjutnya direndam dalam $5 \mathrm{~mL}$ TBS yang mengandung antibodi $5 \mu \mathrm{L}$ ditambah non-fat milk dengan konsentrasi akhir 2\% dan kemudian membran diinkubasi semalam pada suhu kamar sambil digoyang dengan kecepatan $50 \mathrm{rpm}$. Membran kemudian dicuci sebanyak 5 kali dengan Tween $0.05 \%$ dalam TBS (TBST). Membran selanjutnya direndam dalam $5 \mathrm{~mL}$ TBS yang mengandung $5 \mu \mathrm{L}$ konjugat (goat anti rabbit$\operatorname{Ig} G$, Sigma, USA) ditambah non-fat milk dengan konsentrasi akhir $2 \%$ dan kemudian membran diinkubasi selama 60 menit sambil digoyang dengan kecepatan $50 \mathrm{rpm}$. Membran selanjutnya dicuci kembali dengan TBST dan direndam selama 5 menit dalam $10 \mathrm{~mL}$ bufer substrat (Tris- $\mathrm{HCl} 0.1 \mathrm{M}, \mathrm{NaCl} 0.1 \mathrm{M}$ dan $\mathrm{MgCl}_{2} 5 \mathrm{mM}$ ) yang mengandung $66 \mu \mathrm{L}$ nitro blue tetrazolium (NBT) dan $30 \mu \mathrm{L}$ bromo chloro indolil phosphate (BCIP). Bila reaksi positif akan terjadi perubahan warna putih menjadi ungu pada membran nitroselulosa yang telah ditetesi cairan perasan tanaman dan reaksi dapat dihentikan dengan merendam membran dalam $\mathrm{dH}_{2} \mathrm{O}$.

Evalusi metode DIBA dilakukan dengan perlakuan pengenceran sap tanaman hingga $10^{-6}$ dan penggunaan dua membran yang berbeda, yaitu Amersham Hybond ${ }^{\mathrm{TM}}-\mathrm{P}$ dan Nitropure GE untuk menentukan sensitivitas metode deteksi.

\section{Metode Reverse Transcription-Polymerase Chain Reaction}

Tahapan metode deteksi BCMV menggunakan metode RT-PCR terdiri atas tahapan ekstraksi RNA total, transkripsi balik, dan amplifikasi cDNA. Metode ekstraksi RNA dilakukan menggunakan NucleoSpin RNA Plant mini kit dan hasil ekstrak disimpan pada suhu $-80^{\circ} \mathrm{C}$ sampai akan digunakan.

Reaksi transkripsi balik $(10 \mu \mathrm{L})$ terdiri atas $2.2 \mu \mathrm{L}$ water free nuclease, $2 \mu \mathrm{L}$ bufer RT 10x, $0.35 \mu \mathrm{L}$ dNTP $10 \mathrm{mM}, 0.75 \mu \mathrm{L}$ oligo d(T) $10 \mu \mathrm{M}, 0.35 \mu \mathrm{L}$ RNAse Inhibitor, $0.35 \mu \mathrm{L}$ MmULV RT, dan $2 \mu \mathrm{L}$ RNA. Reaksi transkripsi balik dilakukan menggunakan thermal cycler (Gene Amp PCR System 9700) dengan kondisi y:ang telah diatur sebagai berikut: $25^{\circ} \mathrm{C}$ selama 5 menit, $37^{\circ} \mathrm{C}$ selama 90 menit dan $70{ }^{\circ} \mathrm{C}$ selama 15 menit. Hasil akhir reaksi transkripsi balik adalah produk cDNA yang akan digunakan pada reaksi selanjutnya, yaitu amplifikasi.

Amplifikasi dilakukan menggunakan pasangan primer BIC-cpF (5'-TCA GGA ACT GGG CAG CCG CAA C-3') dan BICcpR (5'-CTG CGG GGA ACC CAT GCC AAG-3') (Damayanti et al. 2009). Reaksi amplifikasi $(25 \mu \mathrm{L})$ terdiri atas $16.3 \mu \mathrm{L}$ water free nuclease, $2.5 \mu \mathrm{L}$ PCR buffer, $0.2 \mu \mathrm{L}$ dNTP $2.5 \mu \mathrm{mM}, 2.5 \mu \mathrm{L}$ sucrose creasol, masing-masing $1 \mu \mathrm{L}$ primer BIC-F dan BIC-R (masing-masing $10 \mu \mathrm{M}$ ), $1 \mu \mathrm{L}$ taq polymerase, $1 \mu \mathrm{L}$ cDNA hasil RT. Semua bahan tersebut diisi ke dalam tabung mikro, selanjutnya tabung mikro tersebut dimasukkan ke dalam thermal cycler (Gene Amp PCR System 9700). Amplifikasi BCMV dilakukan sebanyak 35 siklus mengikuti metode Udayashankar et al. (2010) melalui beberapa tahapan: pemisahan utas DNA pada suhu $94{ }^{\circ} \mathrm{C}$ selama 2 menit, penempelan primer pada DNA $68^{\circ} \mathrm{C}$ selama 1 menit dan sintesis DNA pada suhu $72{ }^{\circ} \mathrm{C}$ selama 1 menit. Khusus untuk siklus terakhir ditambah tahapan sintesis selama 10 menit, kemudian siklus berakhir dengan suhu $4{ }^{\circ} \mathrm{C}$.

Evaluasi metode RT-PCR dilakukan dengan perlakuan pengenceran cDNA hingga $10^{-5}$ untuk menentukan batas cDNA yang dapat digunakan untuk deteksi BCMV. 


\section{HASIL}

\section{Deteksi BCMV}

Pengamatan pada metode ELISA secara visual terhadap perubahan warna yang terjadi pada plat mikrotiter ELISA menunjukkan perbedaan intensitas warna kuning. Warna kuning terlihat sangat jelas pada pengenceran sap dengan konsentrasi $10^{-2}$ dan warna kuning semakin berkurang dengan semakin tingginya pengenceran sap tanaman. Demikian pula dengan pengenceran antiserum, semakin tinggi pengenceran maka intensitas warna kuning akan semakin berkurang. Nilai absorbansi ELISA (NAE) pada $405 \mathrm{~nm}$ untuk pengenceran sap dengan konsentrasi $10^{-2}$ dapat mencapai lebih dari 6 kali NAE kontrol negatif bila konsentrasi antiserum yang digunakan ialah $10^{\circ}$ dan $10^{-1}$ (Tabel 1). Nilai absorbansi tersebut menurun mengikuti faktor pengenceran antiserum. Nilai absorbansi ELISA pada pengenceran sap dengan konsentrasi $10^{-3}$ dapat mencapai lebih dari 2 kali NAE kontrol negatif untuk konsentrasi antiserum $10^{0}$ dan $10^{-1}$ dan NAE akan menurun mengikuti faktor pengenceran antiserum. Batas sensitivitas pengujian dengan metode I-ELISA ialah pada tingkat pengenceran sap tanaman dengn konsentrasi $10^{-3}$ dengan pengenceran antiserum $10^{-2}$.

Metode DIBA menggunakan membran Hybond $^{\mathrm{TM}}$-P Amersham dan Nitropure science GE memberikan reaksi positif yang ditandai dengan adanya perubahan warna ungu pada membran (Gambar 1). Reaksi positif yang ditunjukkan oleh warna ungu yang sangat tebal terlihat pada tingkat pengenceran sap dengan konsentrasi $10^{-2}$ namun semakin melemah pada tingkat pengenceran berikutnya. Reaksi positif pada membran Hybond ${ }^{\mathrm{TM}}$-P Amersham dapat terlihat sampai tingkat pengenceran sap $10^{-5}$, sementara pada membran Nitropure science GE reaksi positif terlihat sampai tingkat pengenceran sap $10^{-4}$.

Amplifikasi RT-PCR menggunakan pasangan primer BIC-cpF/BIC-cpR menghasilkan produk yang berukuran sekitar $850 \mathrm{pb}$ (Gambar 2). Pengenceran bertingkat terhadap

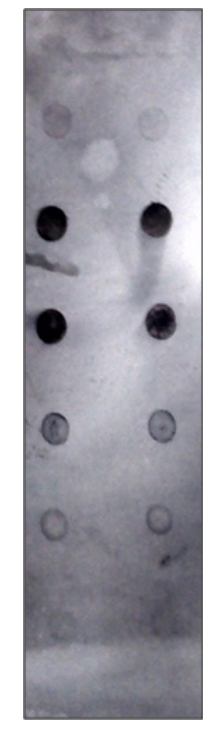

$\mathrm{a}$

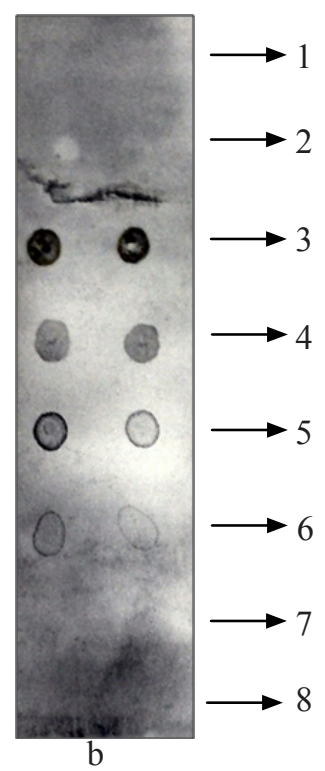

Gambar 1 Reaksi perubahan warna pada metode DIBA dengan berbagai tingkat pengenceran cairan perasan tanaman sakit: a, menggunakan membran Hybond ${ }^{T M}-\mathrm{P}$ Amersham; b, Nitropure science GE. Sampel pada masing-masing membran terdiri atas: 1, bufer; 2, daun tanaman sehat; 3, daun tanaman terinfeksi; 4 sampai 8 , daun tanaman bergejala berturut-turut dengan konsentrasi $10^{-2}, 10^{-3}, 10^{-4}, 10^{-5}$, dan $10^{-6}$.

Tabel 1 Deteksi BCMV menggunakan metode I-ELISA pada berbagai konsentrasi cairan perasan tanaman dan antiserum

\begin{tabular}{lcccccc}
\hline Konsentrasi cairan perasan & \multicolumn{5}{c}{ Konsentrasi antiserum } \\
\cline { 2 - 7 } tanaman terinfeksi & $10^{0}$ & $10^{-1}$ & $10^{-2}$ & $10^{-3}$ & $10^{-4}$ & $10^{-5}$ \\
\hline $10^{-2}$ & ++++ & ++++ & ++ & - & - & - \\
$10^{-3}$ & ++ & ++ & - & - & - & - \\
$10^{-4}$ & - & - & - & - & - & - \\
$10^{-5}$ & - & - & - & - & - & - \\
$10^{-6}$ & - & - & - & - & - & - \\
\hline,- absorban $<2$ kali kontrol negatif; +, nilai absorban 2 kali kontrol negatif; ++, nilai absorban $>2-4$ kali kontrol \\
negatif; +++, nilai absorban $>4$ - 6 kali kontrol negatif; ++++, nilai absorban > 6 kali kontrol negatif.
\end{tabular}




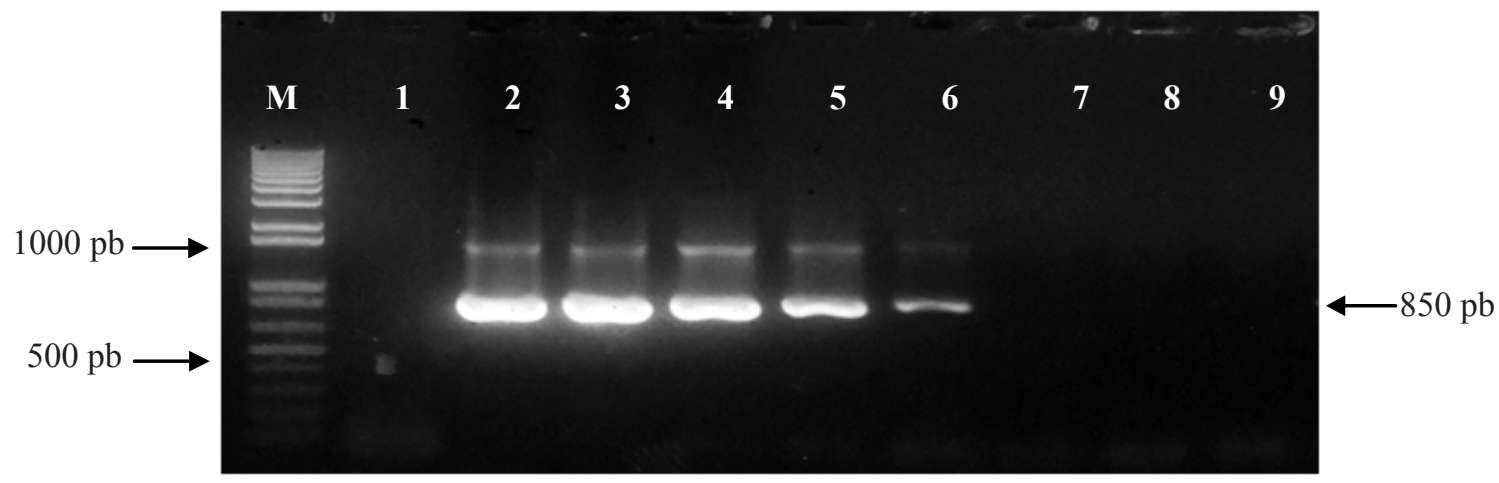

Gambar 2 Hasil amplifikasi RT-PCR dari tanaman kacang panjang terinfeksi BCMV dengan cDNA yang diencerkan bertingkat menggunakan primer BIC-F dan BIC-R. M, penanda DNA $1 \mathrm{~kb} ; 1$, tanaman sehat; $2-9$, sampel cDNA yang diencerkan bertingkat berturut-turut $10^{0}, 10^{-1}$, $10^{-2}, 10^{-3}, 10^{-4}, 10^{-5}, 10^{-6}, 10^{-7}$.

cDNA yang digunakan sebagai DNA cetakan pada tahap amplifikasi menunjukkan bahwa semakin banyak cDNA yang digunakan maka hasil amplifikasi akan semakin jelas. Produk amplifikasi DNA berhubungan dengan konsentrasi cDNA. Pita DNA masih terbentuk pada pengenceran cDNA $10^{-4}$ dan pita tidak terbentuk lagi pada pengenceran $10^{-5}, 10^{-6}$ dan $10^{-7}$.

\section{PEMBAHASAN}

Deteksi dan identifikasi virus dapat dilakukan berdasarkan karakter biologi dan molekuler. Deteksi virus berdasarkan karakter biologi dapat dilakukan dengan pengujian tanaman indikator, penularan, dan bentuk partikel. Deteksi dan identifikasi menggunakan karakter molekuler umumnya dilakukan berdasarkan sifat protein misalnya dengan uji serologi dan sifat asam nukleat dengan hibridisasi DNA, dan PCR/RT-PCR. Metode ELISA dan DIBA merupakan metode serologi yang banyak digunakan untuk mendeteksi dan mengidentifikasi virus tumbuhan. Dalam metode ini antiserum dikonjugasikan dengan enzim sehingga bila ditambahkan substrat enzim maka kompleks antigen-antibodi dalam jumlah yang sedikit saja dapat tervisualisasi. Analisis hasil ELISA dapat dilakukan secara kuantitatif dengan spektrofotometer (ELISA reader), sementara hasil DIBA hanya dapat dianalisis secara kualitatif. Keuntungan metode ELISA ialah sensitivitas yang sangat tinggi sehingga dapat mendeteksi virus pada konsentrasi rendah (1-10 ng $\left.\mathrm{mL}^{-1}\right)$, dapat menguji sampel dalam jumlah banyak secara cepat, menggunakan antiserum sedikit, memperoleh data secara kualitatif dan kuantitatif, dan tahapan pengujian yang mudah.

Deteksi serologi dengan metode I-ELISA memberi hasil positif untuk BCMV sampai pengenceran sap $10^{-3}$ dan pengenceran antiserum $10^{-3}$. Tingkat pengujian yang lebih sensitif diperoleh dengan metode DIBA yang mampu memberikan hasil positif sampai pengenceran sap $10^{-5}$. Batas sensitifitas sap DIBA lebih tinggi dibandingkan dengan metode I-ELISA dan hanya memerlukan antiserum yang lebih sedikit dibandingkan dengan I-ELISA untuk pengujian dengan sampel yang sama.

Saat ini metode deteksi yang banyak digunakan ialah metode deteksi berdasarkan sifat molekuler virus. Metode ini lebih sensitif, akurat, dan lebih efisien dalam penggunaan waktu dan tenaga. Hasil visualisasi elektroforesis menunjukkan bahwa metode RT-PCR berhasil mengamplifikasi BCMV dengan konsentrasi template cDNA yang rendah. Hal tersebut menunjukkan keunggulan teknik PCR yang mampu mendeteksi virus dari jaringan tanaman dengan konsentrasi virus yang rendah.

Metode deteksi I-ELISA, DIBA, dan PCR, memiliki kelebihan dan kekurangan (Tabel 2). Ditinjau dari segi kemudahan pelaksanaan 
Tabel 2 Pembandingan metode I-ELISA, DIBA, dan RT-PCR untuk mendeteksi BCMV pada kacang panjang

\begin{tabular}{lccc}
\hline Faktor Pembanding & \multicolumn{3}{c}{ Metode } \\
\cline { 2 - 4 } & I-ELISA & DIBA & RT-PCR \\
\hline Bobot sampel daun (g) & 0.01 & 0.001 & 0.0002 \\
Akurasi & Sedang-tinggi & Sedang-tinggi & Tinggi \\
Waktu (jam) & $10-30$ & $10-30$ & $3-6.5$ \\
Kapasitas (sampel) & $45-90$ & $45-90$ & 96 \\
Biaya & Sedang-tinggi & Rendah -Sedang & Tinggi \\
\hline
\end{tabular}

pengujian metode I-ELISA dan DIBA dalam menentukan hasil termasuk metode yang mudah dilakukan dan tidak memerlukan alat yang canggih. Hal ini disebabkan hasil I-ELISA dan DIBA dapat ditentukan dengan membandingkan warna substrat antarsampel, kontrol positif, kontrol negatif, dan larutan penyangga. Sebaliknya, RT-PCR tidak dapat dilakukan pada kondisi lapangan karena memerlukan peralatan yang canggih. Teknik RT-PCR memiliki keunggulan pada aspek kecepatan diagnosis. Waktu yang dibutuhkan dalam teknik RT-PCR ialah sekitar 6,5 jam, sedangkan untuk teknik I-ELISA dan DIBA sekitar 10-15 jam. Teknik RT-PCR memiliki tingkat kesulitan yang lebih tinggi daripada teknik I-ELISA dan untuk mendapatkan hasil yang akurat dibutuhkan keterampilan yang tinggi. Berdasarkan kebutuhan biaya pengujian I-ELISA dan DIBA memerlukan biaya lebih rendah dibandingkan RT-PCR karena bahanbahan untuk I-ELISA dan DIBA relatif lebih murah (Kartiningtyas et al. 2006).

Ketersediaan metode deteksi virus yang sangat beragam perlu disikapi dengan tepat dan bijaksana, terutama untuk menetapkan metode yang akan digunakan. Kriteria yang perlu diperhatikan untuk memilih metode deteksi yang akan digunakan ialah sensitivitas, spesifikasi, waktu pengerjaan, dan biaya (Figueira et al. 1997).

\section{DAFTAR PUSTAKA}

Damayanti TA, Alibi OJ, Naidu RA, Rauf A. 2009. Severe outbreak of a yellow mosaic disease on the yard long bean in Bogor, West Java. Hayati J Biosci. 16: 78-82. DOI: http://dx.doi.org/10.4308/hjb.16.2.78.
Figueira AR, Domier LL, D’Arcy CJ. 1997. Comparison of Technique for Detection of Barley yellow dwarf virus-PAV-IL. Plant Dis. 81(11):1236-1246. DOI: 10.1094/ PDIS. 1997.81.11.1236

Kartiningtyas, Hidayat SH. 2006. Deteksi Turnip mosaic virus (TuMV) pada benih dan jaringan daun. J HPT Tropica. 6:3240.

Mahmood T, Hein GL, French RC. 1997. Development of serological procedures for rapid and reliable detection of Wheat streak mosaic virus in a single wheat curl mite. Plant Dis. 81:250-253. DOI: http:// dx.doi.org/10.1094/PDIS.1997.81.3.250.

Nalini MS, Shylaja MD, Prakash HS, Shetty HS. 2006. Production of polyclonal antibody to Bean common mosaic virus and its application in seed health testing. Indian J Microbiol. 46:97-108.

Udayashankar AC, Nayaka SC, Kumar HB, Mortensen CN, Shetty HS, Prakash HS. 2010. Establishing inoculum threshold levels for Bean common mosaic virus strain blackeye cowpea mosaic infection in cowpea seed. African J Biotech. 9(53): 8958-8969. DOI: 10.5897/AJB09.1066.

Verma P, Gupta UP. 2010. Immunological detection of Bean common mosaic virus in French bean (Phaseolus vulgaris L.). Indian J Microbiol. 50: 263-265. DOI: http://dx.doi.org/10.1007/s12088-0100019-8.

Xie Y, Jiao X, Zhou X, Liu H, Ni Y, Wa J. 2013. Highly sensitive serological methods for detecting Tomato yellow leaf curl virus in tomato plants and whiteflies. Virol J. 10:142. DOI: http://dx.doi. org/10.1186/1743-422X-10-142. 